\title{
Plant growth stage influences heavy metal accumulation in leafy vegetables of garden cress and sweet basil
}

\author{
Mohammad Kazem Souri ${ }^{*}$, Mansoure Hatamian ${ }^{2}$ and Tsehaye Tesfamariam ${ }^{3}$
}

\begin{abstract}
Background: Contamination of vegetable crops with heavy metals is a great threat to human health. On the other hand, monitoring plant tissue content of heavy metals at different growth stages could have important implications. In this study, shoot and root samples of garden cress and sweet basil were collected from five farms, from heavy metal polluted fields located in Shahre Rey, south of Tehran, Iran, in either young (3 weeks old) or mature (7 weeks old) plants. The concentrations of cadmium (Cd), lead (Pb), nickel (Ni), arsenic (As), chromium (Cr), cobalt (Co), copper (Cu), manganese $(\mathrm{Mn})$ and zinc $(\mathrm{Zn})$ in plant tissues were determined using atomic absorption spectroscopy. In another study, 2 weeks (young) or 6 weeks old (mature) plants of garden cress were subjected to three concentrations of $\mathrm{Cd}$ and $\mathrm{Pb}\left(0,5,10 \mathrm{mg} \mathrm{L}^{-1}\right)$ under hydroponic sand culture for 5 days, in which Hoagland formula was used for nutrient solution preparation.

Results: The results showed that root concentration of various heavy metals, particularly $\mathrm{Cd}, \mathrm{As}, \mathrm{Ni}, \mathrm{Co}, \mathrm{Cu}, \mathrm{Mn}$ and $\mathrm{Zn}$ but not $\mathrm{Pb}$ were significantly higher than their shoot concentration in either crop under field sampling. The leaf concentration of some heavy metals was significantly different in seedling and older (mature) plant samples of either crop. Young plant leaves of sweet basil had significantly less $\mathrm{Cd}, \mathrm{Pb}$, As and higher $\mathrm{Cu}$ than mature plants, whereas young garden cress plants had similar $\mathrm{Cd}, \mathrm{Pb}$ and higher $\mathrm{As}$ and $\mathrm{Zn}$ concentrations than mature plants. The $\mathrm{Cr}, \mathrm{Co}, \mathrm{Mn}$ and $\mathrm{Zn}$ concentrations were similar in young and mature plants of sweet basil. The $\mathrm{Mn}, \mathrm{Co}, \mathrm{Cr}$ and Ni concentration of young and mature plants of either crop was also similar. The result of hydroponic study showed that young plants of garden cress had higher potential to accumulate lead in shoot and root, particularly in lower $\left(5 \mathrm{mg} \mathrm{L}^{-1}\right)$ than higher (10 $\mathrm{mg} \mathrm{L}^{-1}$ ) lead concentration; however, root $\mathrm{Pb}$ concentration at $10 \mathrm{mg} \mathrm{L}^{-1} \mathrm{~Pb}$ of nutrient solution showed no difference between young and mature plants. Regarding cadmium, young garden cress plants accumulated higher $\mathrm{Cd}$ than mature plants in their shoot, particularly under higher Cd levels (10 rather than $5 \mathrm{mg} \mathrm{L}^{-1}$ ) of nutrient solution; however, a wide difference in root $\mathrm{Cd}$ concentration was observed under low $\left(5 \mathrm{mg} \mathrm{L}^{-1}\right)$ than higher $\left(10 \mathrm{mg} \mathrm{L}^{-1}\right)$ cadmium concentration of nutrient solution.

Conclusion: The results of these two studies indicate that despite that young plants have a higher potential for heavy metal uptake and accumulation, the low difference in young and mature plants in the polluted fields may be due to the longer period of plant growth of mature plants that may increase the risk of exposure to polluted air and dust deposition containing high levels of heavy metals.
\end{abstract}

Keywords: Arsenic, Cadmium, Chromium, Cobalt, Health risk, Lead, Nickel, Wastewater, Zinc

\footnotetext{
*Correspondence: mk.souri@modares.ac.ir

1 Dept. of Horticultural Sciences, Tarbiat Modares University, Tehran, Iran

Full list of author information is available at the end of the article
} 


\section{Background}

Heavy metals in the environment can have potential toxicity on life and human health. Food contamination with heavy metals generally occurs during plant growth by root uptake (from the soil) and/or by leaf absorption from the polluted air. Production of food crops and staple feeds can be managed precisely to have less heavy metal contamination [21]. In soil, total concentration and bioavailability of heavy metals are important factors that can greatly vary by anthropogenic activities and climatic conditions $[17,24]$. The soil concentration and availability of heavy metals have significantly increased during recent decades $[1,22]$. In many arid regions, application of wastewater for agricultural irrigation particularly in vegetable cultivation is the main choice of fresh vegetable production for local markets. A huge body of scientific studies has reported the high levels of heavy metals in the tissue of agricultural crops, particularly vegetables, in polluted urban areas $[5,8,16,21,23,25]$.

Nowadays, food contamination with heavy metals and their harmful impacts on human and environment health is a major challenge in many countries. Various health problems have been reported due to food contamination with heavy metals $[15,17]$.

Industrial activities generally result in severe environmental pollution, particularly in developing countries, where there is no control on environmental impacts of human activities [22]. During the last decades, intensive industrial and cropping activities have dispensed heavy metals into the environment that may finally end in the food chain. The high level of heavy metals in plant tissues is generally due to supply of wastewater as an irrigation source to plants, sewage sludge, and high application rate of chemical fertilizers that have impurities including various heavy metals $[14,17,29]$. There are many reports of high levels of heavy metals in vegetable tissues grown in south of Tehran in Iran [5, 21, 22].

Some of the heavy metals are essential nutrient elements that have a vital role in plant as well as in human normal functioning. Nutrients such as $\mathrm{Fe}, \mathrm{Zn}, \mathrm{Mn}$, $\mathrm{Cu}, \mathrm{Mo}$ and $\mathrm{Co}$ are necessary or beneficial elements that only in high concentration can be toxic to plants $[3,13]$. Nevertheless, the deficiency of micronutrient cations, particularly $\mathrm{Fe}$, is one of the widespread nutritional disorders in dry and calcareous soils that results in reduced plant growth and quality production. The other heavy metals such as $\mathrm{Cd}, \mathrm{Pb}, \mathrm{Cr}$, As, $\mathrm{Ni}$, Se have no known biological function, and generally are considered as negative quality factor and sometimes with toxic effects on plant metabolism [17].

Plants' ability to uptake, transfer and accumulate heavy metals can differ with growth stage, as generally seedlings may have higher uptake rate than mature plants. This difference in uptake is well documented with seedling versus mature plants regarding many necessary mineral nutrients [13]. In addition, the roots seem to have higher concentration of heavy metals than other plant tissues, due to theit direct contact with heavy metals in the soil. The aim of this study was to evaluate the effects of growth stage on accumulation of various heavy metals in leaves and roots of garden cress and sweet basil grown in a farmer's field in southern suburb of Tehran. Therefore, with evaluation of the concentration and dynamics of heavy metals in tissues of leafy vegetables, as well as their potential of uptake and accumulation, it is possible to have better management program for crop growing and the type of consumption.

\section{Materials and methods}

\section{Site characteristics}

Samples of garden cress (Lepidium sativum L.) and sweet basil (Ocimum basilicum) plants were randomly harvested from cultivated farmer's fields in Shahre ReySouth of Tehran, Iran. The region is a major production area of fresh vegetable crops for the capital and the nearby cities. It has a dry and hot climate with annual precipitation less than $200 \mathrm{~mm}$. In the region, there are many small fields of vegetable production that are (directly or indirectly) dependent on streams of domestic and industrial wastewater supply for crops irrigation. In these fields, there is a continuous supply of each vegetable crop with gradual cultivations in 1-3 week intervals. For more than a century, the crop production of the region has been partly or fully dependent on wastewater irrigation, representing the area as polluted.

\section{Field sample collection}

Fields of different sizes were selected for the study, varying from 0.1 to 0.3 ha. Five samples of surface soil (0-30 cm depth) were collected from the fields, which after air drying was passed through a $2 \mathrm{~mm}$ sieve, homogenized and mixed, from which a sample was used for soil analysis. The physicochemical characteristics of the mixed soil are presented in Table 1.

Plant samples were collected during spring (for garden cress) and summer (for sweet basil) of 2011, in which five samples (as replications) were randomly collected from five nearby fields. Each sample consisted of three plants. In the fields, 2 to 3-week-old plants (from emergence) of garden cress (average $1.3 \mathrm{~g} / \mathrm{plant}$ ) and sweet basil (average $0.9 \mathrm{~g} /$ plant) were sampled as young plants (seedling), and 7- to 8-week-old garden cress (average $8.5 \mathrm{~g} /$ plant) and sweet basil (average $6 \mathrm{~g} /$ plant) plants were sampled as mature plants. Plants were precisely pulled out with maximum root system. The roots 
were gently cleaned of soil particles and whole plant samples were packed in paper bags and immediately transferred to a laboratory. Samples from edible parts (leaves) and root tissues of garden cress and sweet basil were used for heavy metal determination. The shoots were separated from the roots, and each part was gently washed with tap water and then distilled water to remove any possible dust on the leaves or soil particles on the roots.

\section{Hydroponic culture}

In another experiment under greenhouse hydroponic culture, 2-week-old (seedling or young plants) and 6-week-old (mature) garden cress plants were used. Plants were grown in black plastic pots (5-6 L volume) filled with sand $(0.05-0.2 \mathrm{~mm})$ and fed with Hoagland nutrient solution containing $\mathrm{Pb}$ and $\mathrm{Cd}$ treatments.

Different levels of $\mathrm{Pb}$ or $\mathrm{Cd}$ including 0,5 and $10 \mathrm{mg} \mathrm{L}^{-1}$ were applied to plants via nutrient solution in a completely randomized design with four replications. Each pot as replicate consisted of five plants. A daily amount of $250 \mathrm{~mL}$ nutrient solution (containing heavy metal levels) was applied to each pot. The young or mature plants were subjected to heavy metal treatments for 5 days. Thereafter, plants were harvested for determination of $\mathrm{Pb}$ and $\mathrm{Cd}$ concentrations of leaf or root tissues. Plants were cut into the shoot and root, and the tissues were washed gently with tap water and distilled water and then dewatered by carefully pressing between tissue papers.

\section{Measurements}

The samples of leaf and root tissues were cut into small pieces and oven-dried at $60{ }^{\circ} \mathrm{C}$ for $48 \mathrm{~h}$. The leaf samples consisted of petiole and blade tissues. The leaf and root samples were ground into powder using a grinding machine, transferred into small plastic bags and stored under dry conditions. At the time of analysis, $1 \mathrm{~g}$ of each sample was transferred to a crucible and placed in a furnace at $550{ }^{\circ} \mathrm{C}$ for $6 \mathrm{~h}$ to obtain dry ash of samples. The full digestion of ashes was performed using drops of $\mathrm{HNO}_{3}(2 \mathrm{~N})$ and then $\mathrm{HCl}(1 \mathrm{~N})$ solutions. The mixture was heated at $70{ }^{\circ} \mathrm{C}$ for 20 min until a light-colored solution was obtained. The residue was washed and filtered into a $50 \mathrm{ml}$ flask using distilled water and Whatman 4 filter paper. Atomic absorption spectrophotometer was used to measure the concentration of different heavy metals in the plant tissues including lead $(\mathrm{Pb})$, cadmium $(\mathrm{Cd})$, chromium $(\mathrm{Cr})$, nickel $(\mathrm{Ni})$, arsenic $(\mathrm{As})$, cobalt $(\mathrm{Co})$, copper $(\mathrm{Cu})$, manganese $(\mathrm{Mn})$ and zinc $(\mathrm{Zn})$. Each sample solution was run in duplicate following the same procedure to give higher creditability of the results obtained. Standard solutions of $\mathrm{Pb}, \mathrm{Cd}, \mathrm{Cr}, \mathrm{Ni}, \mathrm{As}, \mathrm{Co}$, $\mathrm{Zn}, \mathrm{Mn}$ and $\mathrm{Cu}$ were prepared from a stock solution of $1000 \mathrm{mg} \mathrm{L}^{-1}$ in $2 \mathrm{~N} \mathrm{HNO}_{3}$ from MERCK grade of chemicals. A blank sample was also included for better correction and calculation of concentration for all the heavy metals under analysis. Accordingly, the calibration curves were prepared for each element, and the concentration of heavy metals was expressed as $\mathrm{mg} \mathrm{kg}^{-1}$ leaf or root dry weight (DW) [21].

\section{Statistical analysis}

Data were analyzed using SPSS 16 and on the basis of completely randomized design. The differences among treatments were determined at $5 \%$ level by Duncan's test. Graphs and tables were prepared using Microsoft Excel and Word, respectively.

\section{Results}

The results of soil analysis (Table 1) show that high levels of heavy metals are found in the field soil. The results also show relatively high soil $\mathrm{pH}$ and particularly electric conductivity (EC) in the fields under study.

Determination of heavy metals in plant tissues showed that garden cress had higher potential of heavy metal accumulation $(\mathrm{Cd}, \mathrm{Pb}, \mathrm{As}, \mathrm{Ni}, \mathrm{Cr}, \mathrm{Co}, \mathrm{Mn}, \mathrm{Zn}$ and $\mathrm{Cu})$ in root and shoot tissues and consequently higher risk than sweet basil plants (Table 2). In either garden cress or sweet basil, the concentration of all measured heavy metals in root tissue was much higher than leaf tissue concentration, except lead concentration in garden cress that showed no significant difference between root and leaf concentrations. The $\mathrm{Cd}$ concentration in leaves of young garden cress plants was slightly higher than that of mature plants, whereas in sweet basil the $\mathrm{Cd}$ concentration of young plants was significantly less than those of mature plants (Table 2). The lead concentration in mature plants and young plants of garden cress showed a similar trend with no difference (Table 2). In sweet basil, lead concentration of leaves in young plants was considerably less than that of the leaves of mature plants. On the other hand, the difference of

Table 1 The physicochemical characteristics of topsoils collected from the cultivated fields

\begin{tabular}{|c|c|c|c|c|c|c|c|c|c|c|c|}
\hline Texture & $\mathrm{pH}$ & $\begin{array}{l}E C \\
\left(d S m^{-1}\right)\end{array}$ & $\begin{array}{l}\mathrm{Cd} \\
\left(\mathrm{mg} \mathrm{kg}^{-1}\right)\end{array}$ & $\begin{array}{l}\mathrm{Pb} \\
\left(\mathrm{mg} \mathrm{kg}^{-1}\right)\end{array}$ & $\begin{array}{l}\text { As } \\
\left(\mathrm{mg} \mathrm{kg}^{-1}\right)\end{array}$ & $\begin{array}{l}\mathrm{Cr} \\
\left(\mathrm{mg} \mathrm{kg}^{-1}\right)\end{array}$ & $\begin{array}{l}\mathrm{Ni} \\
\left(\mathrm{mg} \mathrm{kg}^{-1}\right)\end{array}$ & $\begin{array}{l}\mathrm{Zn} \\
\left(\mathrm{mg} \mathrm{kg}{ }^{-1}\right)\end{array}$ & $\begin{array}{l}\mathrm{Cu} \\
\left(\mathrm{mg} \mathrm{kg}^{-1}\right)\end{array}$ & $\begin{array}{l}\text { Co } \\
\left(\mathrm{mg} \mathrm{kg}^{-1}\right)\end{array}$ & $\begin{array}{l}\mathrm{Mn} \\
\left(\mathrm{mg} \mathrm{kg}^{-1}\right)\end{array}$ \\
\hline Loamy & 7.4 & 12.1 & 12.2 & 292 & 7.4 & 19.5 & 16.8 & 84.6 & 22.7 & 12.1 & 46.4 \\
\hline
\end{tabular}


Table 2 Heavy metal concentrations ( $\mathrm{mg} \mathrm{kg}^{-1} \mathrm{DW}$ ) in root and leaf tissues of young and mature plants of garden cress and sweet basil

\begin{tabular}{|c|c|c|c|c|c|c|c|c|c|}
\hline Plant samples & $\mathrm{Cd}$ & $\mathrm{Pb}$ & $\mathrm{Ni}$ & As & $\mathrm{Cr}$ & Co & $\mathrm{Zn}$ & Co & $M n$ \\
\hline \multicolumn{10}{|l|}{ Garden cress } \\
\hline Leaves (mature plants) & $4.02 b$ & $39.0 a$ & $6.4 b$ & $1.9 \mathrm{c}$ & $12.7 b$ & $1.14 \mathrm{~b}$ & $46.7 c$ & $19.6 b$ & $79.7 b$ \\
\hline Roots (mature plants) & $7.78 \mathrm{a}$ & $47.4 a$ & $12.2 \mathrm{a}$ & $3.1 \mathrm{a}$ & $27.4 a$ & $3.02 \mathrm{a}$ & $103.5 \mathrm{a}$ & $47.5 \mathrm{a}$ & 131.0a \\
\hline Leaves (seedlings) & $4.43 b$ & $40.4 a$ & $5.8 \mathrm{~b}$ & $2.4 \mathrm{~b}$ & $12.0 \mathrm{~b}$ & $1.37 \mathrm{~b}$ & $66.2 b$ & $20.5 b$ & $79.5 b$ \\
\hline \multicolumn{10}{|l|}{ Sweet basil } \\
\hline Leaves (mature plants) & $1.66 \mathrm{~b}$ & $17.3 b$ & $1.9 b$ & $0.73 b$ & $5.3 b$ & $0.48 b$ & $39.7 b$ & $13.3 c$ & $48.4 \mathrm{~b}$ \\
\hline Roots (mature plants) & $4.04 a$ & $26.1 \mathrm{a}$ & $3.3 a$ & $0.95 \mathrm{a}$ & $18.2 \mathrm{a}$ & $2.47 a$ & $91.0 \mathrm{a}$ & $29.3 a$ & $67.5 \mathrm{a}$ \\
\hline Leaves (seedlings) & $0.90 c$ & $11.7 \mathrm{c}$ & $2.2 \mathrm{~b}$ & $0.62 c$ & $4.2 \mathrm{~b}$ & $0.47 b$ & $41.5 b$ & $16.8 \mathrm{~b}$ & $52.6 \mathrm{~b}$ \\
\hline
\end{tabular}

In each plant and for a given trait, means with at least one common letter are not significantly different at $5 \%$ level of Duncan's multiple range test

root and leaf $\mathrm{Pb}$ concentrations in either plant was lowest among all heavy metals measured in the present study.

In garden cress, nickel concentration in leaves of young plant was slightly less than of mature plants, whereas in sweet basil there was no difference in $\mathrm{Ni}$ concentration between young plant leaves and those of mature plants (Table 2).

In garden cress, young plant leaves had significantly higher arsenic concentration than that of mature plants leaves, whereas in sweet basil plants, leaf As concentration in young plants was less than those of mature plants (Table 2). Regarding leaf chromium concentration (Table 2) and cobalt concentration (Table 2), there was no significant difference between leaves of mature and young plants in either garden cress or sweet basil plant. In garden cress, leaves of young plants accumulated more zinc than leaves of mature plants; however, such effect was not observed in sweet basil plants (Table 2). There was no significant difference in copper concentration of leaves of young and mature garden cress plants (Table 2), whereas in sweet basil those leaves of young plants accumulated more $\mathrm{Cu}$ than mature plant leaves. Regarding manganese concentration of leaves, there was no difference between leaf $\mathrm{Mn}$ concentration of young and mature plants in either crop (Table 2). In addition, the difference between root and leaf concentrations was wider in garden cress than sweet basil plants.

The results of hydroponic experiment showed that in garden cress, young plants have higher potential to accumulate lead in shoot and root, particularly in lower $\left(5 \mathrm{mg} \mathrm{L}^{-1}\right)$ than higher $\left(10 \mathrm{mg} \mathrm{L}^{-1}\right)$ lead concentration (Table 3); however, root $\mathrm{Pb}$ concentration at $10 \mathrm{mg} \mathrm{L}^{-1} \mathrm{~Pb}$ of nutrient solution showed no difference between young and mature plants. Regarding cadmium, young plants accumulate higher $\mathrm{Cd}$ than mature plants in their shoot, particularly under higher $\left(10 \mathrm{mg} \mathrm{L}^{-1}\right.$ than $\left.5 \mathrm{mg} \mathrm{L}^{-1}\right) \mathrm{Cd}$ levels of nutrient solution (Table 4); however, a wide difference in root $\mathrm{Cd}$ concentration was observed under low
Table 3 Effects of different lead $(\mathrm{Pb})$ levels of nutrient solution on root and shoot concentrations of $\mathrm{Pb}\left(\mathrm{mg} \mathrm{kg}^{-1}\right.$ DW) in young and mature plants of garden cress

\begin{tabular}{|c|c|c|c|c|}
\hline \multirow[t]{2}{*}{$\left(\mathrm{mg} \mathrm{L}^{-1}\right)$} & \multicolumn{2}{|l|}{ Shoot $\mathrm{Pb}$} & \multicolumn{2}{|l|}{ Root $\mathrm{Pb}$} \\
\hline & $\begin{array}{l}\text { Young } \\
\text { plants }\end{array}$ & $\begin{array}{l}\text { Mature } \\
\text { plants }\end{array}$ & $\begin{array}{l}\text { Young } \\
\text { plants }\end{array}$ & Mature plants \\
\hline $\mathrm{Pb} 0$ & $0.04 \pm 0.02 c$ & $0.35 \pm 0.13 c$ & OC & Oc \\
\hline $\mathrm{Pb} 5$ & $16.3 \pm 3.06 b$ & $10.8 \pm 1.9 b$ & $239 \pm 24 b$ & $196 \pm 18 b$ \\
\hline $\mathrm{Pb} 10$ & $27.8 \pm 3.12 \mathrm{a}$ & $17.9 \pm 2.6 a$ & $315 \pm 30 a$ & $311 \pm 29 a$ \\
\hline
\end{tabular}

In each plant and for a given trait, means with at least one common letter are not significantly different at $5 \%$ level of Duncan's multiple range test

Table 4 Effects of different cadmium (Cd) levels of nutrient solution in root and shoot concentrations of $\mathrm{Cd}\left(\mathrm{mg} \mathrm{kg}^{-1}\right.$ DW) in young and mature plants of garden cress

\begin{tabular}{|c|c|c|c|c|}
\hline \multirow[t]{2}{*}{$\left(\mathrm{mg} \mathrm{L}^{-1}\right)$} & \multicolumn{2}{|l|}{ Shoot Cd } & \multicolumn{2}{|l|}{ Root Cd } \\
\hline & $\begin{array}{l}\text { Young } \\
\text { plants }\end{array}$ & $\begin{array}{l}\text { Mature } \\
\text { plants }\end{array}$ & $\begin{array}{l}\text { Young } \\
\text { plants }\end{array}$ & Mature plants \\
\hline $\mathrm{CdO}$ & $0.02 \pm 0.008 \mathrm{c}$ & $=0.07 \pm 0.01 b$ & Oc & Oc \\
\hline Cd 5 & $6.25 \pm 0.90 b$ & $4.55 \pm 0.68 a b$ & $342 \pm 33 a b$ & $246 \pm 20 b$ \\
\hline $\mathrm{Cd} 10$ & $11.25 \pm 1.4 \mathrm{a}$ & $5.78 \pm 0.96 a$ & $378 \pm 15 a$ & $348 \pm 18 a$ \\
\hline
\end{tabular}

In each plant and for a given trait, means with at least one common letter are not significantly different at $5 \%$ level of Duncan's multiple range test

(5 $\left.\mathrm{mg} \mathrm{L}^{-1}\right)$ than higher $\left(10 \mathrm{mg} \mathrm{L}^{-1}\right)$ cadmium concentration of nutrient solution.

\section{Discussion}

The concentrations of heavy metals in the fields' soil (Table 1) under study were relatively high compared to the maximum allowable levels in the soil (Table 5). These maximum allowable levels of heavy metals are found in agronomy crops whose grains are mainly consumed. For fresh leafy vegetables the figures need to be set considerably lower than those values. There were significantly higher levels of heavy metal in tissues of these two vegetables 
Table 5 Maximum allowable concentrations of some heavy metals in soil and vegetable tissues (leafy vegetables)

\begin{tabular}{lllllrrrrr}
\hline & Cd & Pb & As & Ni & Cr & Co & Zn & Cu & Mn \\
\hline In plant $\left(\mathrm{mg} \mathrm{kg}^{-1} \mathrm{DW}\right)$ & 2 & 5 & 4.3 & 15 & 5 & 5 & 150 & 50 & 150 \\
In soil $\left(\mathrm{mg} \mathrm{kg}^{-1}\right)$ & 3 & 100 & 20 & 50 & 100 & 50 & 300 & 120 & 400 \\
\hline
\end{tabular}

compared to standard levels in plant tissues. However, there was no toxicity or chlorotic and/or necrotic symptoms on plants under field and hydroponic culture. High levels of heavy metals in soil seem to be mainly due to application of wastewater in the region for irrigation practice. The high value of soil electrical conductivity $(E C)$ is a result of hot climatic conditions of the region, and application of refined wastewater in the region with an EC value of $4.37 \mathrm{dS} \mathrm{m}^{-1}$ [21] may also contribute to soil salt buildup. It has been estimated that an amount of 150-200 ton per day $\mathrm{NaCl}$ enters domestic wastewater in the metropolitan city of Tehran. Moreover, high application rate of chemical fertilizers may also have contributed to higher soil EC of the sites. In the region, application of as much as $600-950 \mathrm{~kg}$ of only urea during the 9 months growing period of vegetable cultivation is a common practice. On the other hand, nitrogen application, particularly in the form of reduced $\mathrm{N}$, could significantly increase soil heavy metal bioavailability $[4,30]$. However, it has been reported that application of $\mathrm{N}$-nitrate can significantly reduce heavy metal concentration of plant leaves $[9,19]$. The region has a dry and hot climate leading to very high evapotranspiration that enhances the negative effects of wastewater irrigation on the soil physiochemical characteristics. Irrigation of vegetable crops with wastewater is a primary source of heavy metal contamination in vegetable tissues $[17,18,21]$.

In the present study, garden cress plants accumulated higher levels of heavy metals, in particular $\mathrm{As}, \mathrm{Ni}, \mathrm{Pb}$ and $\mathrm{Cd}$, in the root and leaf tissues than sweet basil plants. Nevertheless, the most significant difference between the two plants was observed regarding arsenic and nickel. In either plant of garden cress or sweet basil, root concentration of all heavy metals was significantly higher than their corresponding leaf concentrations, except for $\mathrm{Pb}$ in garden cress that showed no difference between root and leaf concentrations. Garden cress is a plant species that can uptake and accumulate relatively high amounts of heavy metals in their shoot tissues. It is a cruciferous plant with heavy metal hyperaccumulator characteristics. In the present study, the young and mature plants that were cultivated in the same fields with relatively high levels of heavy metals showed different uptake rates of heavy metals. The fields have been under wastewater irrigation for many decades of extensive vegetable production in a hot dry climate. The contamination of produced vegetable crops in this region has been reported also in other studies [5, 21].
Heavy metals such as $\mathrm{Cd}, \mathrm{Pb}, \mathrm{As}$, Ni have no role in biological systems including green plants, whereas other trace metals such as $\mathrm{Fe}, \mathrm{Zn}, \mathrm{Cu}$ and $\mathrm{Mn}$ are essential micronutrients necessary for optimal plant growth and production [17]. Plants absorb nutrient elements and heavy metals primarily from the soil by various uptake systems of roots [10, 13]. Nevertheless, the potential to uptake nutrient elements as well as heavy metals varies greatly among plant species $[1$, 11]. Some plant species are highly specialized to absorb and accumulate high levels of specific heavy metals and are known as bioaccumulators [12]. However, vegetable crops are among those in which even low levels of heavy metal can pose great human health risk, mainly due to their fresh consumption in large amounts. The root uptake of heavy metals and their corresponding translocation to plant shoots can be influenced by various factors including climatic, plant genetic, anthropogenic activities and atmospheric deposition [26, 29]. As the results of the present study show, plant developmental stage can also affect the uptake and accumulation of heavy metals in plant tissues. As it was proposed in the present study, young plants showed a higher uptake and accumulation potential for various heavy metals than older plants. The interaction of other factors including environmental conditions and mineral nutrients as well as the interaction of various heavy metals in the medium is quite important in this regard [9].

In the second experiment with hydroponic sand culture, the differences in heavy metal uptake and accumulation of young and mature plants were more significant and evident compared to those plants that were grown in farmer's field. The differences are mainly due to higher root activity in young plants (seedling) than mature older plants. It has been reported that root activity of plants significantly reduces at flowering stage and can be very limited during fruiting and seeding stages [7, 27, 28]. Perhaps, this is the reason why many studies regarding the root activities of nutrient uptake is conducted using young or seedling plants. Plants have generally different sensitivity to various heavy metals. The responses of different plant tissues might be also different for each heavy metal. Reduction in photosynthesis and shoot biomass are common responses of plants to heavy metals $[4,25]$. Root growth and root length are adversely affected by 
heavy metals in onion (Allium cepa) and garden cress plants [2]. In both our experiments, heavy metal concentrations in root tissues were considerably higher than that in leaves. This is mainly due to the fact that the cations of these heavy metals are less mobile in plant than many nutrients, and after uptake are mainly accumulated in root tissues. At least, this is the fact regarding trace metals of $\mathrm{Fe}, \mathrm{Mn}, \mathrm{Zn}$ and $\mathrm{Cu}$ [13]. In addition, roots are the first tissues that have contact with heavy metal ions and the time of exposure is a key factor regarding the final concentration. Moreover, roots generally exudate a wide range of metabolites including organic acids, amino acids, phenolics, sugars and other compounds that can accelerate heavy metal uptake by the root hairs [27]. Higher root concentration of heavy metals indicates that the absorbed metals are subjected to various inactivation, complexation and precipitation processes in root tissues enabling them to move to tissues above.

Environmental pollution represents an important issue in today's life quality. Accordingly, contamination of food and particularly vegetable crops with heavy metals is a big challenge in many countries [17, 21]. In Ghent city in Belgium, spatial analysis of soil heavy metals concentrations showed a high variation in different areas [6]. Vegetable crops, particularly leafy vegetables, are the major source of various minerals, vitamins, antioxidants and many other beneficial food factors for human nutrition; however, in nutritional point of view, leafy vegetables are more susceptible to contamination with higher dosage of heavy metals in their tissues that can pose greater risk to human health $[20,22]$. Therefore, the organic and safe production of vegetable crops, particularly leafy vegetables, is more important than any other crops.

\section{Conclusion}

This study was conducted to evaluate the potential of young (seedling) and mature plants of two vegetable crops of garden cress and sweet basil regarding heavy metals accumulation in their leaf and root tissues for better management of crop production and consumption. The results of the present study showed that in the hydroponic experiment, young garden cress plants showed higher potential to accumulate $\mathrm{Pb}$ or $\mathrm{Cd}$ in their root and particularly leaf tissues. However, under field conditions, this potential was not obviously observed probably due to longer plant growing as well as multiple air, soil and water pollutions that can significantly affect the heavy metal concentrations in leaf tissue. This fact is more important, particularly in mature plants with longer growing period and larger leaf area that facilitate the deposition and absorption of pollutants in the air. The results indicate that in such polluted area, longer plant growing may increase the risk of leaf exposure to dust and heavy metals present in the air. Therefore, no cultivation of food crops, particularly leafy vegetables, is recommended in such a region with soil, water and air pollution.

\section{Abbreviations \\ ppm: parts per million; FW: fresh weight; DW: dry weight; SD: standard deviation.}

\section{Acknowledgements}

This study was conducted with financial support from Iran National Science Foundation (INSF, Grant No 88002063), and we express our thanks to this foundation and those people who helped in conducting this research.

\section{Authors' contributions}

MKS planned the study and prepared the manuscript, MH conducted the experiment (field sampling and laboratory measurements), and TT participated in manuscript writing and analysis of data. All authors read and approved the final manuscript.

\section{Funding}

The study was performed with a grant from Iran National Science Foundation.

Availability of data and materials

Not applicable.

\section{Ethics approval and consent to participate}

All authors listed have contributed significantly to the work performed either in the field or in the laboratory.

\section{Consent for publication}

All authors agree to publish the work.

\section{Competing interests}

The authors declare that they have no competing interests.

\section{Author details}

${ }^{1}$ Dept. of Horticultural Sciences, Tarbiat Modares University, Tehran, Iran.

${ }^{2}$ Dept. of Horticulture, Lorestan University, Khoramabad, Iran. ${ }^{3}$ Institute

of Plant Nutrition, University of Hohenheim, Stuttgart, Germany.

Received: 8 May 2019 Accepted: 4 November 2019

Published online: 02 December 2019

References

1. Alexander PD, Alloway BJ, Dourado AM. Genotypic variations in the accumulation of $\mathrm{Cd}, \mathrm{Cu}, \mathrm{Pb}$ and $\mathrm{Zn}$ exhibited by six commonly grown vegetables. Environ Pollut. 2006;144:736-45.

2. Arambašić MB, Bjelić S, Subakov G. Acute toxicity of heavy metals (copper, lead, zinc), phenol and sodium on Allium cepa L., Lepidium sativum L. and Daphnia magna St.: comparative investigations and the practical applications. Water Res. 1995;29(2):497-503.

3. Bosiacki M, Zieleziński Ł. Phytoextraction of nickel by selected species of lawn grasses from substrates contaminated with heavy metals. Acta Scientarum Polonorum Hortorum Cultus. 2011;10(3):155-73.

4. Cheng MM, Wang P, Kopittke PM, Wang A, Sale PWG, Tang CX. Cadmium accumulation is enhanced by ammonium compared to nitrate in two hyperaccumulators, without affecting speciation. J Exp Bot. 2016;67:5041e5050.

5. Delbari AS, Kulkarni DK. Accumulation of heavy metals in vegetables grown along national high ways-a case study of Tehran-Iran. Int J Eng Sci Invent. 2014;3:77-82.

6. Delbecque N, Verdoodt A. Spatial patterns of heavy metal contamination by urbanization. J Environ Qual. 2016;45(1):9-17.

7. Gao S, Pan WL, Koenig RT. Integrated root system age in relation to plant nutrient uptake activity. Agron J. 1998;90(4):505-10. 
8. Girisha ST, Ragavendra VB. Accumulation of heavy metals in leafy vegetables grown in urban areas by using sewage water and its effect. Archiv Phytopathol Plant Protect. 2006;42(10):956-9.

9. Hatamian M, Rezaie Nejad A, Kafi M, Souri MK, Shahbazi K. Interactions of lead and nitrate on growth characteristics of ornamental judas tree (Cercis siliquastrum). Open Agri. 2018;3:386-92.

10. Hussain D, Haydon MJ, Wang Y, Wong E, Sherson SM, Young J, Camakaris J, Harper JF, Cobbett CS. P-type ATPase heavy metal transporters with roles in essential zinc homeostasis in Arabidopsis. Plant Cell. 2004;16(5):1327-39.

11. Kuboi T, Noguchi A, Yazaki J. Family-dependent cadmium accumulation in higher plants. Plant Soil. 1986;92:405-15.

12. Kumar PN, Dushenkov V, Motto H, Raskin I. Phytoextraction: the use of plants to remove heavy metals from soils. Environ Sci Technol. 1995;29(5):1232-8.

13. Marschner H. Mineral nutrition of higher plants. 3rd ed. London: Academic Press; 2011.

14. Mortvedt JJ. Heavy metal contaminants in inorganic and organic fertilizers. In: Rodriguez-Barrueco, editor. Fertilizers and environment. Dordrecht: Springer; 1996. p. 5-11.

15. Oliver MA. Soil and human health: a review. Eur J Soil Sci. 1997:48(4):573-92.

16. Rattan RK, Datta SP, Chhonkar PK, Suribabu K, Singh AK. Long-term impact of irrigation with sewage effluents on heavy metals content in soils, crops and groundwater-a case study. Agr Ecosyst Environ. 2005; 109:310-22.

17. Sharma RK, Agarwal M, Marshall F. Heavy metal contamination of soil and vegetables in suburban areas of Varansi, India. Ecotoxicol Environ Saf. 2007;66:258-66.

18. Shentu J, He ZH, Yang X, Li T. Accumulation properties of cadmium in a selected Vegetable rotation system of southeastern china. J Agric Food Chem. 2008;56:6382-8.

19. Shi Y, Pu R, Guo L, Man J, Shang B, Ou X, Dai C, Liu P, Cui X, Ye Y. Formula fertilization of nitrogen and potassium fertilizers reduces cadmium accumulation in Panax notoginseng. Archiv Agron Soil Sci. 2019. https:// doi.org/10.1080/03650340.2019.1616176

20. Shin MY, Cho YE, Park C, Sohn HY, Lim JH, Kwun IS. The Contents of Heavy Metals ( $\mathrm{Cd}, \mathrm{Cr}, \mathrm{As}, \mathrm{Pb}, \mathrm{Ni}$, and $\mathrm{Sn}$ ) in the Selected Commercial Yam Powder Products in South Korea. Prev Nutr Food Sci. 2013;18(4):249.
21. Souri MK, Alipanahi N, Hatamian M, Ahmadi M, Tesfamariam T. Elemental profile of heavy metals in garden cress, coriander, lettuce and spinach, commonly cultivated in Kahrizak, South of Tehran-Iran. Open Agric. 2018;3(1):32-7.

22. Souri MK, Alipanahi N, Tohidloo G. Heavy metal content of some leafy vegetable crops grown with waste water in southern suburb of TehranIran. Veg Sci. 2016;43(2):156-62.

23. Sowa I, Wójciak-Kosior M, Kocjan R. The content of some trace elements in selected medicinal plants collected in the province of Lublin. Acta Sci Pol Hortorum Cultus. 2012;11(6):15-22.

24. Suruchi Khanna P. Assessment of heavy metal contamination in different vegetables grown in and around urban areas. Res J Environ Toxicol. 2011:5:162-79.

25. Tyksiński W, Kurdubska J. Differences in cadmium and lead accumulation by lettuce (Lactuca sativa L.) depending on the cultivar. Acta Sci Pol Hortorum Cultus. 2005;4(1):77-83.

26. Vousta D, Gramanis A, Samara C. Trace elements in vegetables grown in an industrial area in relation to soil and air particulate matter. Environ. Pollut. 1996;94:325-35.

27. Walker TS, Bais HP, Grotewold E, Vivanco JM. Root exudation and rhizosphere biology. Plant Physiol. 2003;132(1):44-51.

28. Wang $\mathrm{H}$, Inukai Y, Yamauchi A. Root development and nutrient uptake. Crit Rev Plant Sci. 2006;25(3):279-301.

29. Wei B, Yang L. A review of heavy metal contaminations in urban soils, urban road dusts and agricultural soils from China. Microchem J. 2010;94:99-107.

30. Xie HL, Jiang RF, Zhang FS, McGrath SP, Zhao FJ. Effect of nitrogen form on the rhizosphere dynamics and uptake of cadmium and zinc by the hyperaccumulator Thlaspi caerulescens. Plant Soil. 2009;318(1-2):205-15.

\section{Publisher's Note}

Springer Nature remains neutral with regard to jurisdictional claims in published maps and institutional affiliations.

\section{Submit your manuscript to a SpringerOpen ${ }^{\circ}$ journal and benefit from:}

- Convenient online submission

- Rigorous peer review

- Open access: articles freely available online

- High visibility within the field

- Retaining the copyright to your article

Submit your next manuscript at springeropen.com 